\title{
Educational Diversity and Knowledge Transfers via Inter-firm Labor Mobility
}

Marino, Marianna; Parrotta, Pierpaolo; Pozzoli, Dario

\author{
Document Version \\ Accepted author manuscript \\ Published in: \\ Journal of Economic Behavior \& Organization
}

DOI:

10.1016/j.jebo.2015.10.019

Publication date:

2016

License

CC BY-NC-ND

Citation for published version (APA):

Marino, M., Parrotta, P., \& Pozzoli, D. (2016). Educational Diversity and Knowledge Transfers via Inter-firm Labor Mobility. Journal of Economic Behavior \& Organization, 123, 168-183.

https://doi.org/10.1016/j.jebo.2015.10.019

Link to publication in CBS Research Portal

\section{General rights}

Copyright and moral rights for the publications made accessible in the public portal are retained by the authors and/or other copyright owners and it is a condition of accessing publications that users recognise and abide by the legal requirements associated with these rights.

\section{Take down policy}

If you believe that this document breaches copyright please contact us (research.lib@cbs.dk) providing details, and we will remove access to the work immediately and investigate your claim.

Download date: 26. Apr. 2023

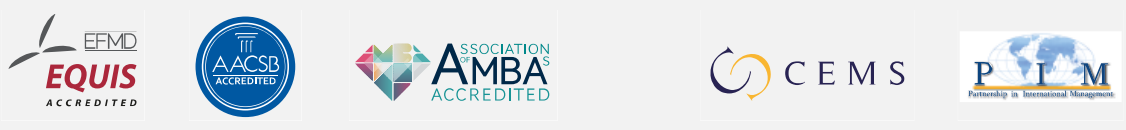




\section{Educational Diversity and Knowledge Transfers via Inter- Firm Labor Mobility}

\section{Marianna Marino, Pierpaolo Parrotta, and Dario Pozzoli}

Journal article (Post print version)

Citation: Educational Diversity and Knowledge Transfers via Inter-firm Labor Mobility. / Marino, Marianna; Parrotta, Pierpaolo; Pozzoli, Dario. In: Journal of Economic Behavior \& Organization, Vol. 123, 03.2016, p. 168-183.

First published online 31 December २०१५.

DOI: 10.1016/j.jebo.2015.10.019

Uploaded to Research@CBS: March २०16

(C) 2016. This manuscript version is made available under the CC-BY-NC-ND 4.0 license http://creativecommons.org/licenses/by-nc-nd/4.0/ 


\title{
Educational Diversity and Knowledge Transfers via Inter-Firm Labor Mobility
}

\author{
Marianna Marino* $\quad$ Pierpaolo Parrotta ${ }^{\dagger} \quad$ Dario Pozzoli ${ }^{\ddagger}$
}

\begin{abstract}
This article contributes to the literature on knowledge transfer via labor mobility by providing new evidence regarding the role of educational diversity in knowledge transfer. In tracing worker flows between firms in Denmark over the period 1995-2005, we find that knowledge carried by workers who have been previously exposed to educationally diverse workforces significantly increases the productivity of the hiring firms. Several extensions of our baseline specification support this finding and confirm that our variable of interest affects the arrival firm's performance mainly through the knowledge transfer channel.
\end{abstract}

JEL Classification: J24, J60, L20.

Keywords: Educational diversity, knowledge transfer, inter-firm labor mobility, firm productivity.

${ }^{*}$ ICN Business School, Department of Strategy and Innovation, 3 Place Edouard Branly, 50070 Metz Technopole, France and Bureau d'Économie Théorique et Appliquée (BETA), UMR CNRS 7522, Université de Lorraine, France. E-mail: marianna.marino@icn-groupe.fr

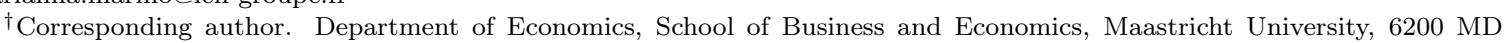
Maastricht, Netherlands. E-mail: p.parrotta@maastrichtuniversity.nl.

$\ddagger$ Funding from the Danish Council for Independent Research/Social Sciences, Grant no. x12-124857/FSE is gratefully acknowledged. Copenhagen Business School, Porcelænshaven 16A, 2000 Frederiksberg, Denmark. 


\section{Introduction}

Worker flows are closely connected to firm outcomes, reflecting the contributions to firm productivity of both incoming workers' human capital and the knowledge that they carry over from previous workplaces. Therefore, inter-firm worker movement provides insight into how inter-firm knowledge transfer typically occurs. However, although scholars have long discussed and relied on the notion of inter-firm transmission of knowledge as a means to explain growth (Lucas, 1988; Romer, 1990; Grossman and Helpman, 1991), they have devoted less attention to the mechanisms governing these knowledge spillovers. Up until now, no study has, for example, investigated how knowledge transfers are linked via labor mobility to the previous exposure of mobile workers to educationally heterogeneous workforces.

When workers move from one firm (the sending or departure firm) to another (the receiving or arrival firm), they carry with them knowledge that they have obtained both from their work and their interactions with co-workers at previous workplaces. Thus, through inter-firm labor mobility, an enterprise may gain access to the knowledge pool to which incoming workers have been exposed in past work environments. This knowledge pool may partly arise from learning-by-using or learning-by-doing activities as acknowledged in early seminal works (Arrow, 1962; Atkinson and Stiglitz, 1969; Nelson and Winter, 1982) and more recent empirical studies (Irwin and Klenow, 1994; Darr et al., 1995; Schilling et al., 2003; Gaynor et al., 2005). The firm knowledge pool may also arise from interpersonal exchanges between co-workers, as documented in a number of studies (Battu et al., 2003; Moretti, 2004; Munch and Skaksen, 2008; Nanda, and Sørensen, 2010). Since Marshall (1890), the firm environment has been viewed as a main locus in which social interactions favor the sharing and transfer of knowledge (Moretti, 2004). Working in close physical and psychological proximity with colleagues can affect the rate of knowledge accumulation of an individual due to his or her exposure to the pool of skills, attitudes to decision making and problem solving and, more generally, the cognitive ability and experience of others. In this context, co-workers represent potential sources of knowledge and information at the individual's disposal that differ from the (usually task-specific) knowledge acquired directly through on-the-job-training and learning-by-doing practices. The likelihood and frequency of social interactions in workplaces induce employees to share what they know and use what they learn in addressing both simple and complex problems. Although co-worker interactions rarely occur without some form of knowledge sharing and exchange, the magnitude of such knowledge transfer is highly context specific. For instance, knowledge transmission is indeed facilitated within the collaborative network of an employee, who is likely to build close interpersonal ties with direct collaborators. More importantly, knowledge transmission and sharing may be particularly related to the heterogeneity of the actors involved.

Researchers have recently examined the contribution of labor heterogeneity to firm productivity by consid- 
ering the direct relationship between these variables without evaluating the possible influence of the workforce composition of the departure firm. Among other studies at the firm level (e.g., Leonard and Levine, 2006; Iranzo et al., 2008), Parrotta et al. (2014a) investigate the existence and magnitude of this direct relationship. On the one hand, the reduced-form analysis reveals that labor diversity in education is significantly and positively associated with firm productivity for all the sectors included in the analysis. On the other hand, the estimated parameters of the structural production function governing the substitutability between labor types suggest that, for about half of the sectors, skill diversity arising only among highly educated workers is positively associated with firm productivity. This evidence is consistent with the theoretical predictions of Lazear (1999), who argues that labor diversity in terms of educational background is productivity enhancing if one worker's information set is relevant to and does not overlap with another's. Therefore, whereas informational asymmetry is detrimental to the productivity of individuals working in isolation, it is a necessary condition for effective knowledge sharing among co-workers within organizations. However, Parrotta et al. (2014a) also finds that ethnic and demographic heterogeneity generally does not positively correlate with productivity, suggesting that the negative effects of the communication and integration costs associated with a more demographically and culturally diverse workforce counteract the positive effects of diversity that arise from enhanced creativity and knowledge spillover (Lazear, 1999; Glaeser et al., 2000; and Alesina and La Ferrara, 2005).

Concerning the role of knowledge transfers via labor mobility, we know that labor flows between firm pairs are a conventional proxy for knowledge transfer. Earlier studies have traced the movement of specific categories of workers - such as engineers (Almeida and Kogut, 1999), R\&D workers (Maliranta et al., 2009), and scientists and technical personnel (Tambe et al., 2013), and have focused on labor mobility as producing knowledge transfers from foreign-owned (Balsvik, 2011; Poole, 2012), R\&D-intensive (Moen, 2005), patenting (Kim and Marschke, 2005) or more productive (Stoyanov and Zubanov, 2012) firms, all of which enjoy clear competitive advantages. Nevertheless, Parrotta and Pozzoli (2012) provide evidence that labor mobility is a potential channel for knowledge spillover within a broader set of firms in both the manufacturing and service sectors, introducing a deep and generalized process of learning-by-hiring into the economy. ${ }^{1}$ Although Parrotta and Pozzoli (2012) provide critical details regarding the general knowledge transmission mechanism, they do not explore how differences in co-worker profiles in previous workplaces may encourage knowledge transmission. Examining this aspect is our main goal in this paper. Specifically, we investigate whether and to what extent past workforce diversity in education affects arrival firm productivity.

Based on the evidence provided in both fields of studies, we expect to observe that, with all other things being equal, a more heterogeneous departure firm's educational pool results in a more likely knowledge trans-

\footnotetext{
${ }^{1}$ Pioneering studies on the concept of learning by hiring include Song et al. (2003) and Rosenkopf and Almeida (2003).
} 
fer from the departure firm to the arrival firm through labor mobility. Thus, interactions with co-workers who have heterogeneous knowledge due to their different educational backgrounds may create an opportunity for new combinations of knowledge and skill complementarities and may promote learning opportunities that can eventually be transferred to firms through labor mobility. Identifying and measuring the economic consequences of the spillovers generated by the educational heterogeneity of previous co-workers is clearly important for a complete comprehension of the various factors that play a role in determining firm performance as well as sharpening our understanding of how the well-documented (firm-specific) benefits from the educational diversification of labor inputs can be transmitted to other firms in the economy. The primary aim of the present research is to test the hypothesis that firm productivity benefits from educational labor diversity of other enterprises because the flow of workers among firms facilitates the acquisition of considerable portions of the knowledge pool characterizing departure firms. This finding would provide evidence that workers in more educationally heterogeneous workplaces can access a valuable part of a firm's knowledge pool and carry it with them when they change employers. ${ }^{2}$

It is worth underlining that the effect of knowledge transfer originating from the exposure to an educationally diverse workforce should not be confused with any unobservable preference characteristic of movers, such as the 'ability to work with different people' or 'attitudes towards exerting effort', because in our estimation strategy we take into account (i) the level of educational diversity of the arrival firm, and (ii) the contribution of labor input, which is measured by including the potential knowledge carrier inflow. By doing (i) we can safely rule out the possibility that our estimations merely pick up movers' sorting into highly diverse workplaces, whereas controlling for (ii) allows us to separate out the knowledge spillover effect from the impact of newly hired employees' human capital or their partial labor force contribution to firm productivity. Furthermore, in treating the average departure firm's educational diversity as production input that is selected by the firm, we overcome potential issues of endogeneity and collinearity by allowing firms to observe productivity shocks before hiring knowledge carriers, following the approach suggested by Ackerberg et al. (forthcoming). Addressing potential endogeneity problems in this fashion is of fundamental importance for the empirical analysis, which otherwise may suffer from severe bias related to the key parameters of interest.

Our findings suggest that knowledge transfers are productivity enhancing when they originate from educationally diversified departure firm workforces. On average, a one-standard-deviation increase in such knowledge transmission increases arrival firm productivity by approximately 1 percent. A battery of tests reveal that a larger effect is generally estimated when we consider sending firms that are more likely to be knowledge intensive, such as patenting or exporting firms. The same holds true when we look at movers with

\footnotetext{
${ }^{2}$ This knowledge transfer is also a key factor in starting a new business. Indeed, Marino et al. (2012) find that educational diversity promotes entrepreneurial behavior (transitions from employment to self-employment) among employees.
} 
a higher capacity for absorbing knowledge from previous jobs, e.g., highly educated workers, workers with a managerial positions or workers with longer tenures within their departure firms. This allows us to underpin the relevance of the channel of knowledge transfer to explain the productivity enhancing effect stemming from educationally diverse departure firm workforces. However, the fact that the same effect - though of lower magnitude - remains positive and statistically significant, even for other categories of departure firms or movers, allows us to safely dismiss the idea that the new hires who were previously exposed to educationally diverse workforces may benefit the arrival firms exclusively when they fulfill certain standards in terms of education, occupation, ability or when they originate from specific types of firms.

The structure of the remainder of this paper is as follows. Section 2 briefly describes the data and provides information on the main variables of interest, as well as the descriptive statistics. Section 3 explains the empirical strategy that we have implemented in detail. Section 4 explains the results of our empirical analysis, and Section 5 offers concluding remarks.

\section{Data}

\subsection{Data sources}

We use two different Danish register data sets that can be linked to each other thanks to their common firm identifiers. Both data sources are administered by Statistics Denmark, and together, they provide data for the time period 1995-2005.

The master data set is the "Integrated Database for Labor Market Research" (henceforth IDA) database, a longitudinal employer-employee register that contains annual information for each individual employed in the recorded population of Danish firms during the period 1980-2005 (see Parrotta and Pozzoli 2012 for further details on the variables that are included in IDA). In our final data set, we include individuals (i) who are 18 to 60 years old, (ii) who have stable occupations (i.e., students, trainees and part-time employees are disregarded), (iii) who have positive labor income and (iv) who belong to neither the top nor the bottom percentile of the earning distribution. In addition, transitions that may have resulted from mergers or acquisitions, i.e., transitions in which more than half of an enterprise's workforce moves to the same arrival firm, are not considered as job-to-job labor flows.

The retrieved information is then aggregated at the firm level to obtain data regarding firm size, partial/total foreign ownership, whether the firm includes more than one establishment (plant) and detailed workforce composition characteristics - labor diversity, among others. ${ }^{3}$

\footnotetext{
${ }^{3}$ The next subsection provides a detailed description of how labor diversity is calculated.
} 
The second data source, REGNSKAB, provides the following information about the firms' business accounts: value added (calculated as the difference between total sales and the costs of intermediate goods), materials (intermediate goods), capital (fixed assets) and related industry. ${ }^{4}$ All of the companies in the final sample that were used in the empirical analysis have at least 10 employees and are not in one of the following sectors: i) agriculture, fishing and quarrying; ii) electricity, gas and water supply and iii) public services. Furthermore, all firms with imputed accounting variables are excluded from the analysis.

The key features of the sources used to construct our final data set are that they provide extensive data regarding employees and firms and that it is possible to match the records from the two sources. Both features make the data set especially suitable for our purposes, as they enable us to examine moving workers for each year, along with their departure and arrival firms.

\subsection{Variables}

This section mainly describes our measures of inter-firm knowledge transfer via worker mobility, where knowledge arises from labor diversity. First, we identify mobile workers and their associated departure and arrival firms.

Second, for each labor inflow, i.e., inflow involving the same departure and arrival firms, we calculate the educational diversity to which the given set of workers has been exposed during the previous year. As in Parrotta et al. (2014b), we sum the Herfindahl indices calculated for each workplace belonging to the same multi-plant firm, ${ }^{5}$ weighted by the number of individuals employed at each workplace, as follows:

$$
\text { diversity }_{i t}=\sum_{w=1}^{W} \frac{N_{w}}{N_{i}}\left(1-\sum_{s=1}^{S} p_{s w t}^{2}\right)
$$

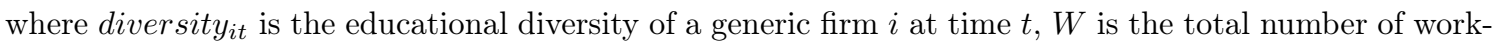
places belonging to firm $i, S$ is the total number of educational categories, ${ }^{6}$ and $N_{w}$ and $N_{i}$ are respectively the total number of employees of workplace $w$ in firm $i .^{7}$ Thus, the ratio between the last two variables corresponds to the weighting function, while $p_{s w t}$ is the proportion of employees falling into each category $s$ at time $t$ in each workplace. Following Marino et al. (2012), we compute departure firm workforce diversity

\footnotetext{
${ }^{4}$ See Parrotta and Pozzoli 2012 for further details on how REGNSKAB was constructed.

${ }^{5}$ For mono-establishment firms, the ratio $\frac{N_{w}}{N_{i}}$ equals one and therefore diversity is directly measured as the Herfindahl index at the firm level.

${ }^{6}$ Educational categories comprise the eight highest levels of education achieved by the employees in our sample: primary education, secondary education (general high school, business high school, vocational education) and tertiary education (engineering, humanities, natural sciences, and social sciences) (Parrotta et al., 2014a; and Marino et al., 2012).

${ }^{7}$ By calculating diversity as in (1), we assume that educational diversity between and within workplaces contributes to the index in the same way. We indirectly test the impact of this assumption on the estimation of the knowledge transfer effect by excluding multi-establishment departure firms from the analysis, as described in the subsection 4.2.
} 
excluding mobile workers and their characteristics. When calculating arrival/receiving firm workforce diversity, by contrast, we include the inflow of newly hired employees. This is done to strengthen the exogeneity of our knowledge spillover index with respect to the movers' characteristics. However, in the robustness check section, we also provide the results obtained by including (excluding) mobile workers in the calculation of departure (arrival) firm workforce diversity.

Finally, we calculate a measure of inter-firm knowledge transfers, $k t$. This variable is constructed as a simple average $^{8}$ of the educational diversity associated with all departure firms, $D$ ( $d$ refers to a single departure firm from which at least one worker moves to arrival firm) $i$ at time $t$ :

$$
k t_{i t}=\frac{\sum_{d=1}^{D} \text { diversity }_{d t-1}}{D}
$$

To complement the analysis of the role of educational diversity, we also calculate a measure of inter-firm knowledge transfer that examines ethnic and demographic diversity, separately. More details on how sending firm diversity is measured in terms of these two dimensions are provided in Appendix 1.

\subsection{Descriptive statistics}

Because the main hypothesis of this paper is that educational mobility is a channel for knowledge transmission between firm pairs, we devote particular attention in our final data set to documenting worker flows.

As reported in Table 1, the final sample consists of 126,463 observations involving approximately 12,000 firms over the sample period 1995-2005. Unsurprisingly, approximately 70 percent of the observations involve firms with fewer than 50 employees, as the Danish industrial structure is dominated by small firms. ${ }^{9}$ Compared with larger firms, small companies are more likely to be single-plant operations and, not surprisingly, have substantially lower levels of value added, materials and capital stock. ${ }^{10}$ Moreover, whereas small firms are characterized by large shares of blue-collar and relatively younger employees, companies with more than 50 employees tend to have slightly larger proportions of foreigners, middle managers and employees with tertiary education in their workforces. Given the relatively low level of foreign capital penetration in the Danish economy, ${ }^{11}$ large differences in the shares of foreign ownership for small and large firms are not observed. In addition, no substantial differences are recorded in the inflows of new workers, average tenure and the

\footnotetext{
${ }^{8}$ We also perform estimations by using a weighted average measure of educational diversity associated with the departure firms; see Section 4.1 for further details.

${ }^{9}$ According to the OECD (2005), the population of Danish firms mainly consists of small and medium-sized companies. Firms with fewer than 50 employees account for 97 percent of firms and represent 42 percent of employment in manufacturing and services.

${ }^{10}$ Accounting values are reported in thousands of real DKK. Monetary Values, retrieved from the World Bank database, are deflated using the GDP deflator with 2000 as the base year.

${ }^{11}$ In 2008, less than 1 percent of all private firms in Denmark were foreign-owned (Økonomi- og Erhvervsministeriet, 2011). Indeed, Danish firms invest abroad more than foreign firms do in Denmark. This pattern is consistent with the observation that Danish firms are very active in offshoring labor-intensive manufacturing to low-cost countries, whereas Denmark does not attract substantial investments from foreign manufacturing firms (Carlsen and Melgaard Jensen, 2008).
} 
shares of men and workers with primary or secondary education. Interestingly, large firms show consistently higher values for labor diversity than do small firms, ${ }^{12}$ and large firms appear to recruit employees from firms with more heterogeneous workforces. This finding may be consistent with the assumption that larger firms typically focus more on knowledge management practices than small firms and may be more aware of the benefits of labor poaching than small companies.

Table 2 provides information on the characteristics of mobile workers for the year they move, averaged over the sample period. These workers represent approximately 13 percent of the overall workforce and generally are younger, have shorter tenures and have less work experience than immobile workers. We generally observe that movers coming from departure firms with above-average labor diversity levels are slightly more likely to be women, hold managerial positions and be better educated.

Finally, Table 3 shows that the majority of job changes (as a share of the total labor force over the period 1995-2005) occurs within the service industries, particularly in transport (27 percent) followed by construction (17 percent), financial and business services (16 percent) and wholesale and retail trade (15 percent). A slightly larger degree of job mobility is observed within rather than between industries.

\section{$3 \quad$ Estimation strategy}

One of the major issues discussed in the literature concerning firm production functions is the simultaneity (endogeneity) affecting the estimation of parameters on input variables. In fact, there could be factors (shocks) influencing production that are unobserved by econometricians but are observed by the firm. Hence, firms may respond to positive (negative) productivity shocks by expanding (reducing) their output, which requires a higher quantity and/or quality of production inputs. A number of estimation approaches have been developed to address the simultaneity issue, such as those advocated by Olley and Pakes (1996) (OP henceforth) and Levinsohn and Petrin (2003) (LP henceforth). These approaches have been extensively used and propose the identification of a proxy variable (investments for the former and materials for the latter), that being a strictly increasing function of the time-varying productivity shocks, may allow for the consistent estimation of the input parameters. However, Ackerberg, Caves and Frazen (forthcoming) (ACF henceforth) show that OP and LP can suffer from potential collinearity problems and thus propose an improved estimation approach. In line with ACF, Wooldridge (2009) suggests an estimation approach that also addresses the simultaneity issue but follows the LP rationale more closely.

\footnotetext{
${ }^{12}$ It is important to clarify that the scope of diversity does not mechanically increase with firm size. This can be explained with a simple example. Let us assume that there are 5 possible categories of employees, and let us compare two firms with 10 and 100 employees, respectively. The two firms would have exactly the same level of diversity if their workforces equally represented all possible categories, i.e., if there were 2 and 20 employees for each category in the first and second firm, respectively. For both firms the diversity index would equal $\left(1-\left((0.2)^{2} \times 5\right)\right)$.
} 
For our empirical analysis, we implement the structural techniques suggested by ACF, being the most commonly recognized way to properly cope with the simultaneity when identifying the input coefficients. More specifically, we estimate firm productivity by using a Cobb-Douglas production function that contains real value added, $Y$, labor, $L$, capital, $C$; and a set of additional variable inputs. These additional inputs are our measure of knowledge transfer, $k t$, and a vector for workforce composition, $X$, for both arrival and departure firms. The latter in particular includes the arrival firm average tenure and the share of foreigners, managers, middle managers, males, workers with either tertiary or secondary education and differently aged workers belonging to the employees' age distribution quintile. The same vector also include the departure firms' average shares of: foreigners, managers, middle managers, males, workers with either tertiary or secondary education and differently aged workers belonging to the employees' age distribution quintiles. ${ }^{13}$

Similarly to Parrotta and Pozzoli (2012), the log-linear production function is therefore specified as follows:

$$
y_{i t}=\text { cons }+\alpha l_{i t}+\beta c_{i t}+\gamma k t_{i t}+\delta X_{i t}+u_{i t}
$$

where lower-case letters refer to log-variables and the error term $u_{i t}$ consists of a time-varying firm specific effect $v_{i t}$, unobserved by econometricians and correlated with the input variables, and an uncorrelated idiosyncratic component $\varepsilon_{i t}$. Using materials as a proxy variable and assuming that the latter is chosen after labor as suggested in $\mathrm{ACF}$, we use the following moments to identify the coefficients on $c, l, k t$, and $X$ :

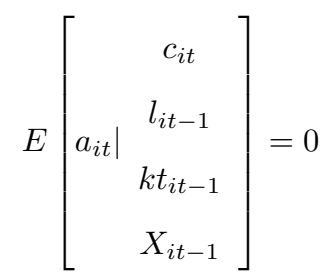

where $a_{i t}$ is the innovation term to the productivity shock $v_{i t}$, which is modelled as a first-order Markov process and can be approximated by a non-parametric function of the input variables in (2). ${ }^{14}$

\footnotetext{
${ }^{13}$ We also specify other control variables for partial/total foreign ownership, whether a firm includes multiple establishments, year and industry dummies because such variables can potentially affect productivity.

${ }^{14}$ We specify a fourth degree polynomial (with cross-interactions) in the first stage of the ACF algorithm and a third degree polynomial in $v_{i t}$ to compute the first-order Markov process.
} 


\section{Results}

\subsection{Main results}

Our main findings are reported in Table 4. The first column contains the OLS estimates. The second column shows the results obtained by estimating equation (1) with the algorithm suggested by OP (1996), which allows for the control of sample selection issues and deals with firm exit. The third column includes the estimates from Wooldridge's approach (2009), and all of the other columns show parameters from our preferred method (i.e., the ACF approach), given that this approach appears to be one of the most suitable ways to properly address simultaneity in identifying the input coefficients, as extensively outlined in Söderbom and Bond (2005) and Ackerberg et al. (forthcoming). The first 4 columns do not include the additional variable inputs, $X$, in addition to our measure of inter-firm knowledge transfer, $k t$; they are instead added in column 6 to investigate whether our parameter of interest changes in terms of its sign, size or significance level. ${ }^{15}$ Column 5 adds to the basic specification the arrival firm educational diversity.

The first two rows in Table 4 report the labor and capital elasticities, which differ slightly across the methods and specifications used. Specifically, the labor (capital) elasticity tends to be lower (higher) when standard OLS is used than when the OP, Wooldridge and ACF methods are used (columns 2, 3 and 4). Therefore, as in other studies (Ackerberg et al. forthcoming; Konings and Vanormelingen 2015), a lower (higher) labor (capital) contribution is found when endogeneity and similtaneity issues are controlled for. ${ }^{16}$ Furthermore, comparing the estimated elasticities across the OP, Wooldridge and ACF methods, we find that even though the OP and Wooldridge estimates of the labor and capital coefficients are slightly smaller than their ACF counterparts, all these input elasticities are fairly comparable. For the sake of brevity, we therefore proceed by discussing the results obtained with only the ACF approach. With respect to the other input variables, the proportion of employees with secondary and tertiary education, the proportion of longer-tenured workers, and the share of foreign and male workers are all statistically significant and carry a positive sign (column 6). The results also show that productivity is positively correlated with the educational diversity of the arrival firm (columns 5 and 6), confirming the evidence provided in Parrotta et al. (2014a).

Our variable of interest, the measure of knowledge transfer along the educational dimension, enters the production function with a positive sign, i.e., the average educational diversity of the departure firms positively affects the receiving firm productivity. Taking the sixth column, which includes all of the controls and

\footnotetext{
${ }^{15}$ However, all specifications include standard control variables: a foreign-ownership dummy, a multi-establishment dummy and a set of 3-digit industry and year dummies.

${ }^{16}$ The lower sample sizes in columns (2)-(6) compared to column (1) are explained by the fact that the utilized structural estimation methods are dynamic approaches that require at least two lagged values of the production function inputs. Moreover, when running the OP estimations, we need to exclude observations with zero investment (approximately 10 percent of the sample). The OLS results for the smaller samples are fairly similar to the ones reported in column (1) and are available upon request from the authors.
} 
therefore contains our more reliable estimates, we find that a one-standard-deviation increase in the knowledge transfer index leads to a productivity enhancement of approximately $0.7(0.189 \times 0.037)$ percent. To facilitate the interpretation of our variable of interest, we have also calculated our knowledge transfer index, which is restricted to cases of single, double and triple movements for each pair of departure-arrival firms. ${ }^{17}$ The regression results for this empirical exercise are reported in Table 5 and show that a hypothetical firm that hires one worker from another firm whose educational diversity is one standard deviation higher than the average level experiences a $0.5(0.189 \times 0.027)$ percent productivity gain. An hypothetical firm hiring two (three) workers from the same departure firm, whose educational diversity is one standard deviation higher than the average level, experiences about 1 (1.5) percent productivity gain. The effect of educational diversity therefore increases almost proportionally in terms of the number of movers who are hired from the same sending firms. This finding may suggest that if a receiving firm hires most of its workers from one particular departure firm, the educational diversity of the latter should count more towards the productivity-enhancing effect. We therefore proceed by estimating the knowledge transfer effect with a weighted version of our index, which is calculated as follows:

$$
w k t_{i t}=\sum_{d=1}^{D} \frac{n_{d t}}{N_{i t}}\left(\text { diver sity }_{d t-1}\right)
$$

where $n_{d t}$ represents the total number of hires from a specific departure firm $d$ and $N_{i t}$ is the total number of hires of arrival firm $i$ for a given year $t$. The estimated coefficient on the modified index $w k t_{i t}$ is reported in column 4 of Table 5 and is only slightly larger than the one obtained from the simple average index.

\subsection{Mechanisms involved: the role of knowledge transfers}

In the following steps, we assess whether the previous results are consistent with the hypothesis on knowledge diffusion via labor mobility by exploiting the variation in types of departure firms and movers' characteristics. While these tests provide useful insight into the channel through which the skill diversity of the sending firms affects the arrival firm's productivity, it is important to emphasize that they are only suggestive and are not conclusive evidence of this particular mechanism. Given that the results on the "hypothetical firm" experiment reported in Table 5 clearly show the importance of weighting for the number of movers from each sending firm, we proceed with the weighted index (see equation 4) for the remainder of the empirical analysis.

\footnotetext{
${ }^{17}$ In such cases, we assign a missing value to our knowledge transfer index respectively if: i) more than one mover is hired from the same departure firm; ii) more or fewer than 2 movers are hired from the same departure firm; and iii) more or fewer than 3 movers are hired from the same departure firm.
} 
We begin by investigating whether the relative importance of knowledge transfer varies across different types of sending firms. This step is done to evaluate whether the impact of skill diversity through labor mobility increases if the departure firm is more likely to be a knowledge intensive company. Specifically, the latter is alternatively defined as a firm that i) has at least one patent application at the European Patent Office, ${ }^{18}$, ii) export goods or services, iii) has foreign shareholders, iv) has a total factor productivity ${ }^{19}$ larger than that of the arrival company, v) has a share of tertiary level-educated workers above the industrial median during the year before the hire, vi) belongs to R\&D-intensive industries, or iv) is a multi-establishment or large company. We therefore distinguish newly hired workers depending on whether they move from one of the firm types reported above or not, and we re-calculate our knowledge transfer measure separately for both cases. We then include both measures in the production function (see equation 2) to test whether their estimated coefficients are statistically different. The results from all these refinements are reported in Table 6 and clearly show that the impact of the knowledge transfer from educationally diverse workplaces tends to be statistically greater when associated with firms deemed to have a large endowment of knowledge (i.e., patenting or exporting firms, very productive firms, firms with a large amount of human capital or firms that belong to R\&D intensive industries). Surprisingly, the knowledge transfer effect does not appear to be stronger for large firms (i.e., multi-establishment companies or firms with more than 50 employees) compared to small firms (i.e., mono-establishment companies or firms with fewer than 50 employees). One reason behind this apparently puzzling result may be grounded in the fact that the firm's size does not necessarily reflect its knowledge base and potential. Furthermore, the estimated coefficient for our knowledge transfer variable is larger in magnitude for foreign-owned companies compared to domestic companies, yet it is not precisely estimated. This can be explained, on the one hand, by the small number of firms identified with this specific characteristic in our sample and, on the other, by the fact that among firms that are defined as "domestic" in our sample, there are also multi-national companies (i.e., Danish companies with offices abroad). In the last column of Table 6, we also assess whether the impact of sending firms' skill diversity varies depending on whether we consider within or between industry mobility flows. The results from this additional exercise show that arrival firms benefit more in terms of the acquired knowledge from intra-industry worker flows than from inter-industry ones, as the estimated coefficient of our knowledge transfer measure for within-industry labor mobility flows is statistically larger than the estimated coefficient for between-industry flows. This may indicate that knowledge transfers can more easily yield productivity gains when they originate with

\footnotetext{
${ }^{18}$ Information on patent applications is drawn from the database of patent applications sent to the European Patent Office (EPO) by Danish firms. Access to these data has been made possible by the Center for Economic and Business Research (CEBR), an independent research center affiliated with the Copenhagen Business School (CBS). The data set covers a period of 28 years (1978-2005) and allows us to account for approximately 3,000 applicants, corresponding to nearly 2,500 unique firms. More details concerning the construction and composition of the data set can be found in Kaiser et al. (2015).

${ }^{19}$ Total factor productivity is estimated separately by a 2-digit industry level by using ACF.
} 
co-workers who are employed in similar environments and core businesses. As in Stoyanov and Zubanov (2012), we therefore find that the knowledge introduced to firms by newly hired workers is mostly industry specific.

All in all, these results for the different types of sending firms underpin the relevance of considering the channel of knowledge transfers to explain the main findings reported in the previous section. The results also allow us to safely dismiss the idea that the new hires may benefit the arrival firms exclusively when they originate from highly productive, innovative and internationalized firms, from employers that pay more (typically larger companies) or from firms with a large endowment of human capital due to a highly educated workforce, as the estimated coefficient for our knowledge transfer variable also remains positive and statistically significant when we don't consider those categories of firms. Furthermore, the fact that the estimated coefficient for our knowledge transfer variable is also statistically significant for small firms (those with fewer than 50 employees) suggests that the variable does not simply capture the effect of hiring employees from vertically integrated firms or large firms with a broad scope in general. Hence, knowledge transfer through interaction with educationally diverse co-workers is a broad phenomenon that involves the entire production system rather than specific categories of enterprises, although this knowledge transfer is magnified in more knowledge-based contexts and workplaces, in line with our theoretical surmise on knowledge transfers.

To further qualify the role that knowledge transfers played in our empirical results, we now investigate whether the sending firms' diversity affects the arrival firm's productivity to a different extent, depending on the movers' ability to "absorb" knowledge from the exposure to educationally heterogeneous workplaces. The previous literature in this field (Song et al., 2003; Kaiser et al., 2015; Parrotta and Pozzoli, 2012; Stoyanov and Zubanov, 2012) has in fact shown that worker characteristics (i.e., education, occupation and certain unobserved traits such as motivation) are notably related to their ability to retain knowledge from previous jobs and transfer it to new contexts. Based on Table 7, we can evaluate whether newly hired workers' education, unobserved ability, nationality, occupation and tenure within their departure firms affect the magnitude of the knowledge transfer effects. For each mover characteristic, we separately calculate two knowledge transfer measures and include both measures in the same regression. Starting with occupation, we divide new hires into two categories, managers and non-managers. For both occupational categories, we find a significant, positive contribution of spillover from past co-workers' educational diversity to the productivity levels of the arrival firms. Our results, however, suggest that the knowledge transfer that occurs through manager mobility is much greater than the knowledge transfer associated with non-managers. Stronger effects are also found when we look at knowledge transfers stemming from native workers compared to foreign hires or from workers with either a tertiary education or a tenure of at least two years at the departure firms compared 
to movers with a below-tertiary education and less than 2 years of tenure. By dividing new hires according to whether their fixed effects estimated from a wage equation ${ }^{20}$ are above/below the mean of the overall fixed effects distribution of the sending firms, we find that the knowledge spillover effect is statistically larger when we focus on the movers with above-mean fixed effects compared to the effect obtained by considering movers with below-average abilities. We also split knowledge carriers depending on whether they have received at least a 5 percent wage increase after being hired by the arrival firm. While most of the job transitions identified in the data set are voluntary, we believe that wage increases may indicate a strong signal of the employer's willingness to poach workers from a specific sending firm. As expected, we find a larger effect on our variable of interest when we look at movers who experience wage increases of at least 5 percent.

All these findings by movers' characteristics strengthen the role of knowledge in our estimations and are consistent with the assumption that more able workers or workers with more education or longer job tenure are generally better at retaining and transferring firm-specific knowledge, because of their superior cognitive skills or their greater amount of time spent accumulating and absorbing knowledge through interactions with co-workers. However, the fact that our coefficient of interest remains positive and statistically significant even when we focus on knowledge carriers with lower education or with a blue-collar occupation or below median ability allows us to dismiss the surmise that the effect estimated on our knowledge spillovers variable is merely due to the movers' quality, productivity, ability or human capital.

The two groups of findings discussed in this section seem to support the hypothesis that mobile workers, who come from firms characterized by high educational diversity and therefore have had contact with coworkers with different educational backgrounds, may transfer valuable knowledge to the arrival firm and thus positively affect its performance. Hence, in moving from one firm to another, workers may be able to carry more valuable knowledge with them if they have been exposed to greater educational diversity at the workplace level. Interestingly, we find similar results in the main analysis with respect to diversity within arrival firms: diversity of educational background within an arrival firm's labor force is positively associated with firm productivity (see also Parrotta et al., 2014a). All these results, taken together, are consistent with the hypothesis that interactions with co-workers with heterogeneous education and skills may facilitate new combinations of knowledge and skill complementarities.

\footnotetext{
${ }^{20}$ We measure the unobserved ability of each mover, independent of observed time-variant worker characteristics and any firm-specific effects, as the time-invariant worker effect estimated from the wage equation à la Abowd, Kramarz and Margolis (1999). To estimate both fixed effects, we have to maintain the assumption of exogenous mobility conditional on the observables. Card et al. 2013 show that this assumption is consistent with data. Moreover, the identification of both worker and firm fixed effects requires a high level of mobility of workers across firms to determine the groups of connected workers and firms. Bagger, Sørensen and Vejlin (2013) argue that in the Danish context, there is sufficient job-to-job mobility to identify both fixed effects, given that the labor market is one of the most flexible in the world with exceptionally high turnover rates. In our data set, only $0.43 \%$ of the observations are disconnected.
} 


\subsection{Robustness checks}

In this section, as a part of our robustness checks, we first evaluate the variations in the coefficients estimated for the knowledge transfer variable that result when this variable is calculated in various ways. First, as workers may interact not only with their colleagues but also with other individuals living or working in the geographic area in which departure firms are located, we alternatively calculate our measure of knowledge transfers by calculating a weighted average of the departure firms' diversity measured at the commuting area level. $^{21}$ Measuring diversity at this level of geographical aggregation ${ }^{22}$ surely helps us to understand whether knowledge transfer originates from interactions not only with co-workers but also with other people within the commuting area (e.g., friends). It is noteworthy that in this test, we do not include the mobility flows in which both the departure and arrival companies are located in the same commuting area. If we did, it would be more difficult to capture any geographically specific effects, given that both the arrival and the departure firms could benefit from the same geographical educational heterogeneity. Using our chosen approach, we find that the coefficient of our measure of knowledge transfer is positive but insignificant, as reported in the first column of Table 8. This finding provides evidence that knowledge transfers that are profitable from the firm viewpoint mainly originates from co-worker interactions.

In the second column, we re-calculate our knowledge transfer variable from equation (4) by including the contribution of mobile workers to the (previous year) diversity of the departure firm. This is done to take into account the cases in which an educationally divergent worker leaves an otherwise homogenous firm and, consequently, to avoid a situation where our index measures no diversity when in fact the mobile worker is exposed to a situation of educational diversity. The results reported in the third column of Table 9 allow us to dismiss this concern, given that the estimated coefficient on our variable of interest is qualitatively similar to the one estimated in the main analysis (see the last column of Table 5).

In the last two columns of Table 8, we test whether the exposure of mobile workers to ethnic or demographic diversity enhances the productivity of arrival firms. The coefficients that we estimate for these spillover measures are positive but insignificant. This finding may be a function of communication barriers due to differences in language, values, age, and gender, which may have somehow hindered co-worker interactions and, therefore, the knowledge exchange between colleagues. Hence, according to our analysis, educational heterogeneity is the main source of valuable knowledge transmission among co-workers.

We then proceed by examining whether there is any change in the coefficients of our knowledge transfer variable for different sub-samples of arrival firms (Table A2.1 and A2.2). First, the importance of knowledge transfer via labor mobility and that of departure firms' educational diversity seems particularly heightened in

\footnotetext{
${ }^{21}$ Using the algorithm suggested in Andersen et al. (2000), we have identified approximately 100 commuting areas.

${ }^{22}$ The commuting area diversity is calculated excluding among knowledge carriers all individuals who are employed at the sending firms.
} 
manufacturing, wholesale and retail trade, and financial and business services. Thus, it appears that spillover from more educationally diverse workforces is a general phenomenon that induces larger productivity gains in both service and manufacturing industries. It also appears that the spillover related to the average departure firm's educational heterogeneity remains significant and increases with the size of the arrival firm's workforce. The estimates for single-establishment companies are very similar to our main findings, which is likely because such firms represent the majority of the enterprises in the sample. We finally exclude all firms located in Copenhagen and the surrounding area because large cities usually have a more diverse supply of workers and a larger percentage of highly productive firms. ${ }^{23}$ The results obtained using this exclusion do not qualitatively differ from those reported in the main analysis.Combining all these findings together with those on different types of movers discussed in the previous section shows that the estimated coefficient on our knowledge transfer variable does not simply capture the positive sorting of high-quality mobile workers, i.e. the fact that high-quality workers are more likely to be at firms with high educational diversity, and at the same time more likely to be poached by another firm with high-productivity in the future (Bartolucci and Devicienti, 2012; Card et al., 2013; Serafinelli, 2013).

\section{Conclusions}

This article investigates the effect of hiring workers from educationally diverse enterprises on firm productivity. In particular, we evaluate how arrival firm productivity is affected by the average educational diversity of departure firms when inter-firm labor mobility exists. From this perspective, workers who were previously exposed to educationally heterogeneous co-workers are viewed as potential knowledge carriers.

To assess these learning effects, we estimate firm productivity using the algorithm suggested by Ackerberg et al. (forthcoming), which allows us to address the endogeneity and collinearity issues that typically arise when structural estimation methods are used with production functions.

We find that hiring workers who have had contact and relationships with co-workers with different educational backgrounds seems to beneficial to arrival firm productivity because such interactions may encourage the transfer of complementary knowledge, enriching the arrival firm's knowledge pool. Thus, our findings support the hypothesis that the exposure of poached employees to past co-workers with different educational backgrounds promotes learning opportunities in arrival firms.

The benefits from departure firms' educational diversity are particularly policy relevant because these benefits are distributed throughout the entire economy. However, knowledge transfers tend to be stronger when associated with larger, more innovative, more productive or more export-oriented firms. Indeed, these

\footnotetext{
${ }^{23}$ The only real agglomeration area in Denmark is Copenhagen and its environs.
} 
firms typically present a large endowment of knowledge that can be absorbed, carried and transferred by mobile workers. Furthermore, we find that workers with high education levels or longer job tenure are generally better at retaining and transferring firm-specific knowledge because of their superior cognitive skills or longer exposure to their co-workers' knowledge.

The evidence that the average sending firm's educational diversity contributes to arrival firm productivity may suggest that firms devote more attention to the educational composition of the labor force from which they recruit their workers. In addition, public institutions might implement policies that are intended to ease inter-firm labor mobility (e.g., by reducing rigidity in the labor market) and favor education in different fields of study (e.g., by boosting investment in education). 


\section{References}

[1] Abowd, J.M., Kramarz, F., Margolis, D.N., 1999. High Wage Workers and High Wage Firms. Econometrica, 67, 271-333.

[2] Adsera, A., Pytlikova, M., 2015. The Role of Language in Shaping International Migration. Economic Journal, Feature Issue, 125, F49-F81.

[3] Ackerberg, D.A., Caves, K., Frazer, G. Identification Properties of Recent Production Function Estimators. Forthcoming in Econometrica.

[4] Alesina, A., La Ferrara, E., 2005. Ethnic Diversity and Economic Performance. Journal of Economic Literature, 43, 762-800.

[5] Almeida, P., Kogut, B., 1999. Localization of knowledge and the mobility of engineers in regional networks. Management Science, 45.7, 905-917.

[6] Andersen, A.K., 2000. Commuting Areas in Denmark. Copenhagen, AKF forlaget.

[7] Arrow, K.J., 1962. The economic implications of learning by doing. Review of Economic Studies, 29(3), $155-173$.

[8] Atkinson, A.B., Stiglitz, J.E., 1969. A new view of technological change. The Economic Journal, 573-578.

[9] Bagger, J., Sørensen, K.L., Vejlin, R., 2013. Wage sorting trends. Economics Letters, 118, 63-67.

[10] Balsvik, R., 2011. Is Labor Mobility a Channel for Spillovers from Multinationals? Evidence from Norwegian Manufacturing. Review of Economics and Statistics, 93, 285-297.

[11] Bartolucci, C., Devicienti, F., 2012. Better Workers Move to Better Firms: A Simple Test to Identify Sorting. Carlo Alberto Notebooks 259, Collegio Carlo Alberto.

[12] Battu, H., Belfield, C.R., Sloane, P.J., 2003. Human Capital Spillovers within the Workplace: Evidence for Great Britain. Oxford Bulletin of Economics and Statistics, 65(5), 575-594.

[13] Card, D., Heining, J., Kline, P., 2013. Workplace Heterogeneity and the Rise of West German Wage Inequality. Quarterly Journal of Economics, 128, 967-1015.

[14] Carlsen, M., Jensen, A.M., 2008. Globalisation and Danish Direct Investments. Danmarks Nationalbank Monetary Review, 51-66. 
[15] Darr, E.D., Argote, L., Epple, D., 1995. The acquisition, transfer, and depreciation of knowledge in service organizations: Productivity in franchises. Management Science, 41(11), 1750-1762.

[16] Gaynor, M., Seider, H., Vogt, W.B., 2005. The volume-outcome effect, scale economies, and learningby-doing. American Economic Review, 243-247.

[17] Glaeser, E., Laibson, D.I., Scheinkman, J.A., Soutter, C.L., 2000. Measuring Trust. The Quarterly Journal of Economics, 115, 811-846.

[18] Grossman, G.M., Helpman, E., 1991. Innovation and Growth in the Global Economy. Cambridge, MIT Press.

[19] Guiso, L., Sapienza, P., Zingales, L., 2009. Cultural Biases in Economic Exchange? Quarterly Journal of Economics, 124, 1095-1131.

[20] Hong, L., Page, S.E., 2001. Problem Solving by Heterogeneous Agents. Journal of Economic Theory, 97 (2001), 123-163.

[21] Iranzo, S., Schivardi, F., Tosetti, E., 2008. Skill Dispersion and Firm Productivity: An Analysis with Employer-Employee Matched Data. Journal of Labor Economics, 26, 247-285.

[22] Irwin, D.A., Klenow, P.J., 1994. Learning-by-doing spillovers in the semiconductor industry. Journal of Political Economy, 1200-1227.

[23] Kaiser, U., Kongsted, H.C., Rønde, T., 2015. Does the mobility of R\&D labor increase innovation? Journal of Economic Behavior \& Organization, 110, 91-105.

[24] Kim, J., Marschke, G., 2005. Labor mobility of scientists, technological diffusion, and the firm's patenting decision. The RAND Journal of Economics, 36, 298-317.

[25] Konings, J., Vanormelingen, S., 2015. The Impact of Training on Productivity and Wages: Firm Level Evidence. Review of Economics and Statistics 97.2, 485-497.

[26] Lazear, E.P., 1999. Globalisation and the Market for Team-Mates. The Economic Journal, 109, 15-40.

[27] Lazear, E.P., 2004. Balanced Skills and Entrepreneurship. American Economic Review, Papers and Proceedings 94, 208-11.

[28] Leonard, J.S., Levine, D.I., 2006. Diversity, Discrimination, and Performance. Institute for Research and Employment Working Paper 147, 2006. 
[29] Levinsohn, J., Petrin, A., 2003. Estimating production functions using inputs to control for unobservables. The Review of Economic Studies, 70.2, 317-341.

[30] Lucas, R.E. Jr., 1988. On the mechanism of economic growth. Journal of Monetary Economics, 22, 3-42.

[31] Maliranta, M., Mohnen, P., Rouvinen, P., 2009. Is inter-firm labor mobility a channel of knowledge spillovers? Evidence from a linked employer-employee panel. Industrial and Corporate Change, 18.6, 1161-1191.

[32] Marino, M., Parrotta, P., Pozzoli, D., 2012. Does Labor Diversity Promote Entrepreneurship? Economics Letters, 116, 15-19.

[33] Marshall, A., 1890. Principles of economics. New York, Macmillan.

[34] Moen, J., 2005. Is Mobility of Technical Personnel a Source of R\&D Spillovers? Journal of Labor Economics, 23, 81-114.

[35] Moretti, E., 2004. Workers' Education, Spillovers and Productivity: Evidence from Plant-Level Production Functions. American Economic Review, 94 (2004).

[36] Munch, J.R., Skaksen, J.R., 2008. Human capital and wages in exporting firms. Journal of International Economics, 75(2), 363-372.

[37] Nanda, R., Sørensen, J.B., 2010. Workplace peers and entrepreneurship. Management Science, 56(7), 1116-1126.

[38] Nelson, R.R., Winter, S.G., 1982. The Schumpeterian tradeoff revisited. The American Economic Review, 114-132.

[39] Olley, G.S., Pakes, A., 1996. The Dynamics of Productivity in the Telecommunications Equipment Industry. Econometrica, 64, 1263-1297.

[40] Parrotta, P., Pozzoli, D., 2012. The Effect of Learning by Hiring on Productivity. The RAND Journal of Economics, 43, 167-185.

[41] Parrotta, P., Pozzoli, D., Pytlikova, M., 2014a. Labor Diversity and Firm Productivity? European Economic Review, 66, 144-179.

[42] Parrotta, P., Pozzoli, D., Pytlikova, M., 2014b. The Nexus between Labor Diversity and Firm's Innovation? Journal of Population Economics, 27.2, 303-364. 
[43] Poole, J.P., 2013. Knowledge Transfers from Multinational to Domestic Firms: Evidence from Worker Mobility. Review of Economics and Statistics, 95(2), 393-406.

[44] Romer, P.M., 1990. Endogenous Technological Change. Journal of Political Economy, 98, 71-102.

[45] Rosenkopf, L., Almeida, P., 2003. Overcoming local search through alliances and mobility. Management Science, 49, 751-766.

[46] Serafinelli, M., 2014. Good Firms, Worker Flows and Local Productivity. mimeo, University of Toronto.

[47] Schilling, M.A., Vidal, P., Ployhart, R.E., Marangoni, A., 2003. Learning by doing something else: Variation, relatedness, and the learning curve. Management Science, 49(1), 39-56.

[48] Soderbom, M., Bond, S., 2005. Adjustment costs and the identification of Cobb Douglas production functions. IFS Working Papers.

[49] Song, J., Almeida, P., Wu, G., 2003. Learning-by-hiring: when is mobility more likely to facilitate interfirm knowledge transfer? Management Science, 49, 351-365.

[50] Stoyanov, A., Zubanov, N., 2012. Productivity Spillovers Across Firms through Worker Mobility. American Economic Journal: Applied Economics, 4, 168-198.

[51] Tambe, P., Lorin, M.H., 2013. Job hopping, information technology spillovers, and productivity growth. Management Science, , 60(2), 338-355.

[52] Wooldridge, J.M., 2009. On estimating firm-level production functions using proxy variables to control for unobservables. Economics Letters, 104(3), 112-114. 


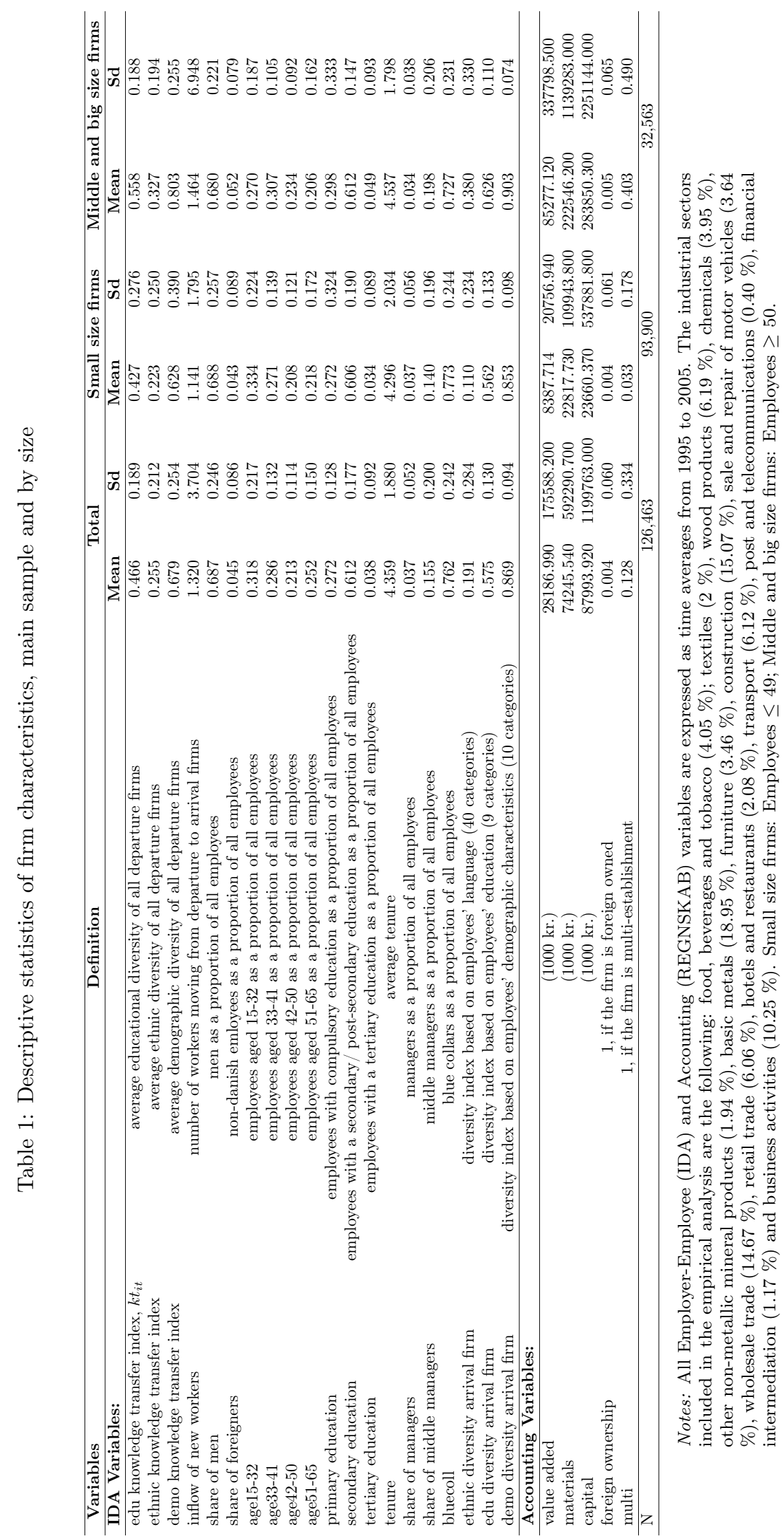




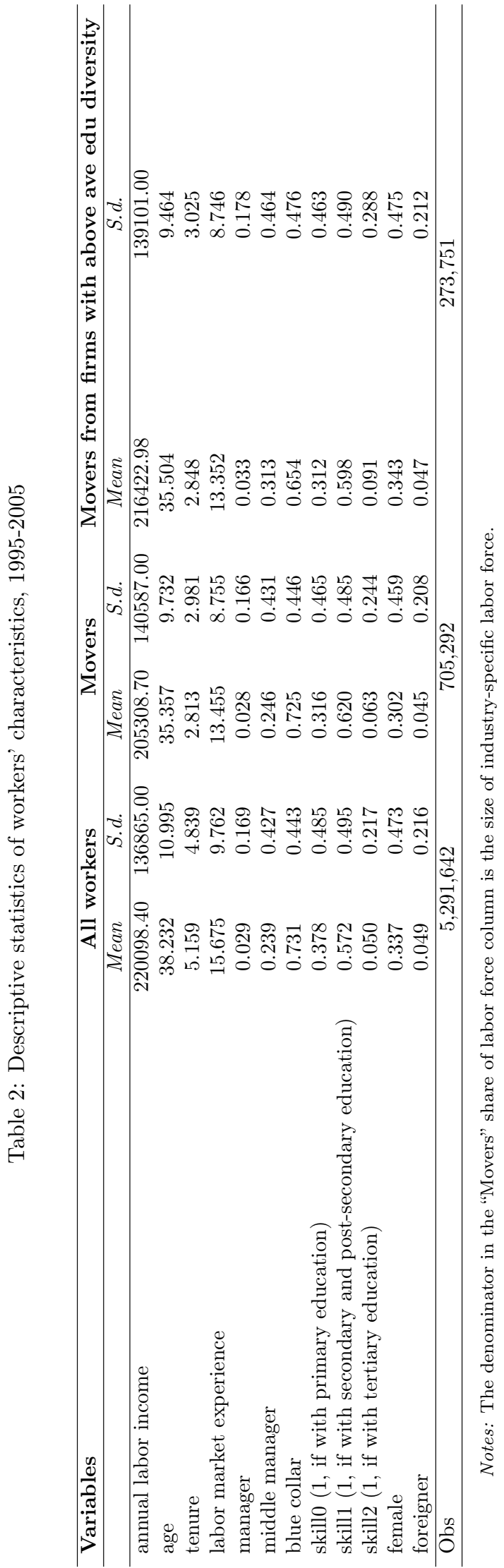




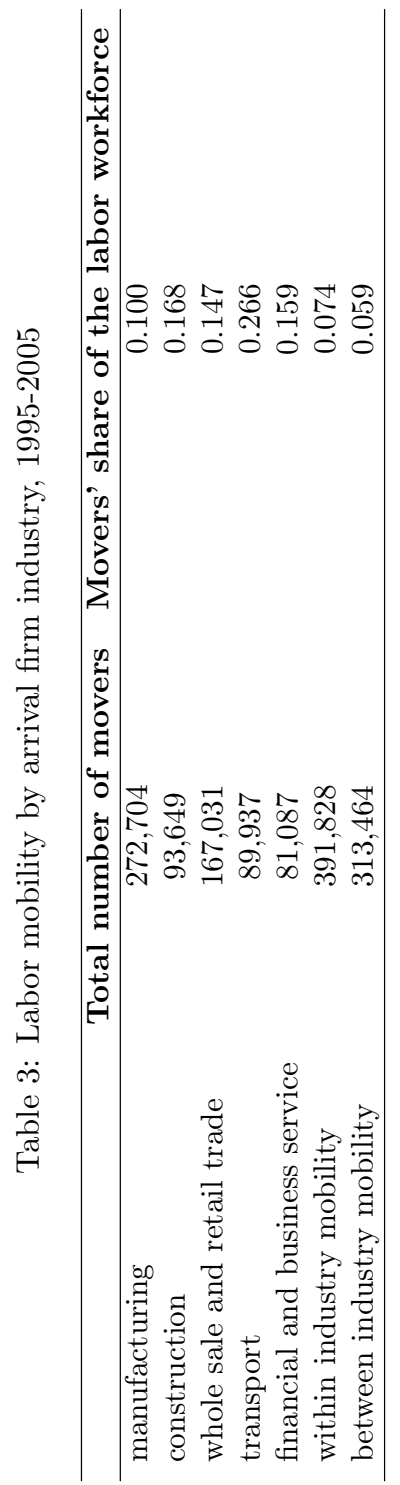




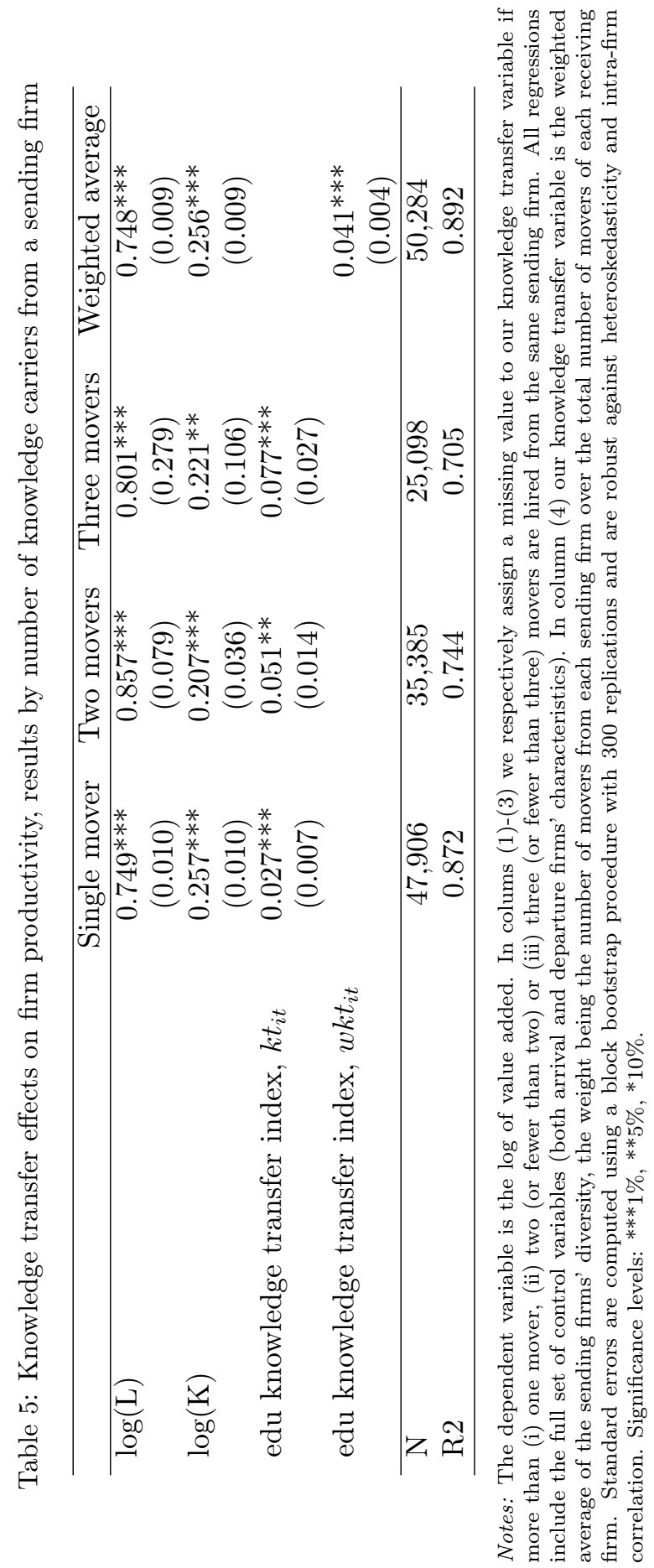




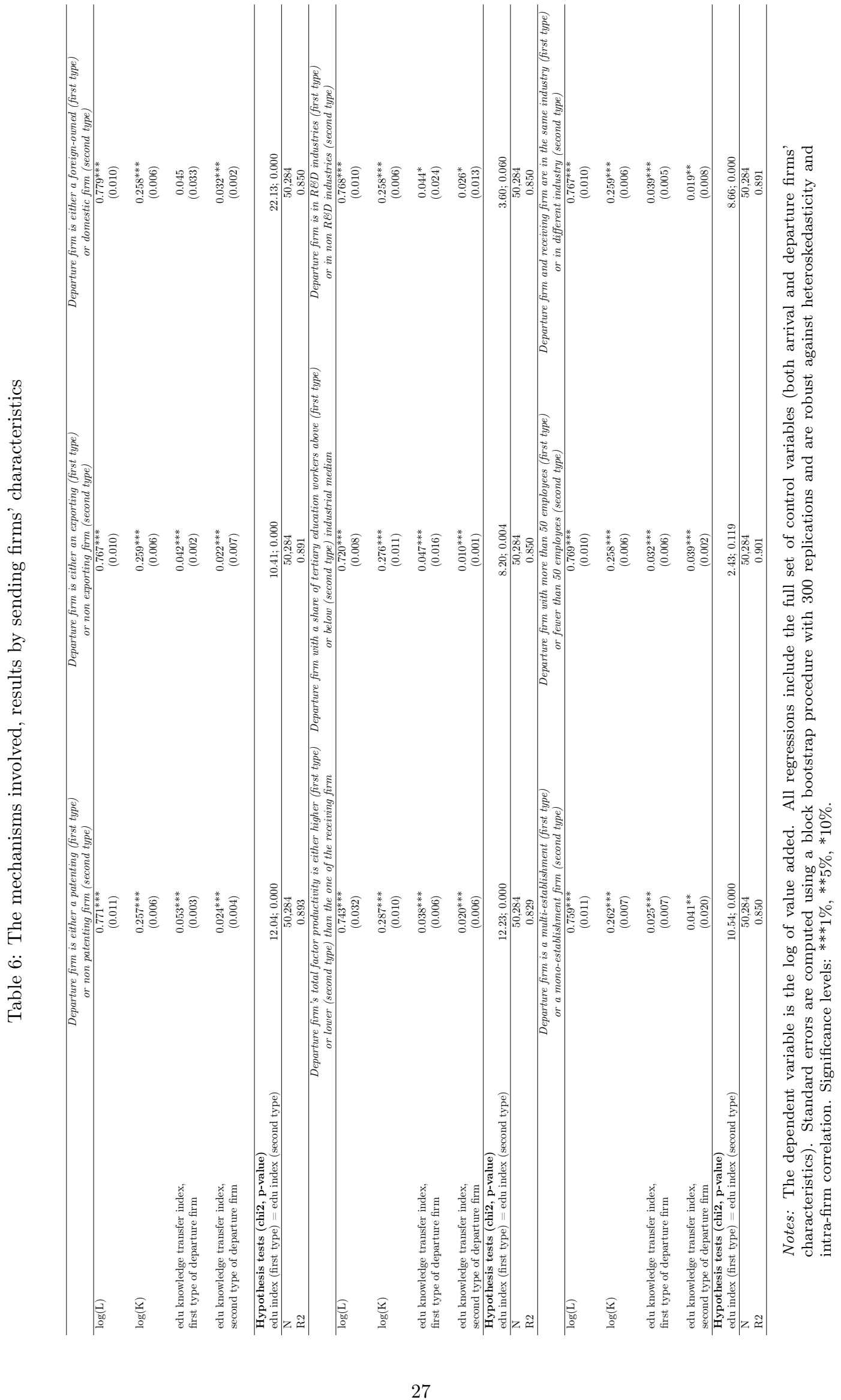




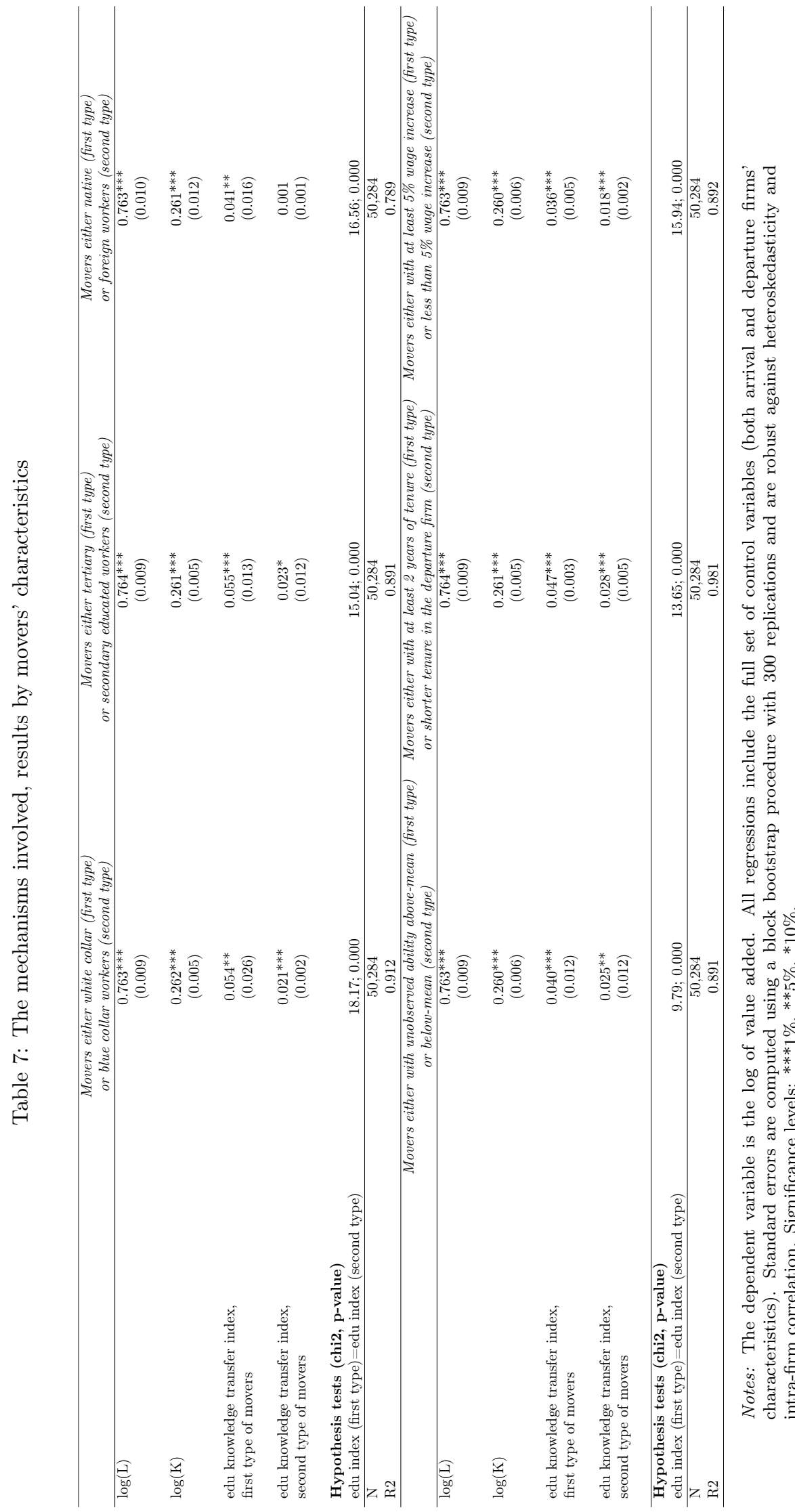




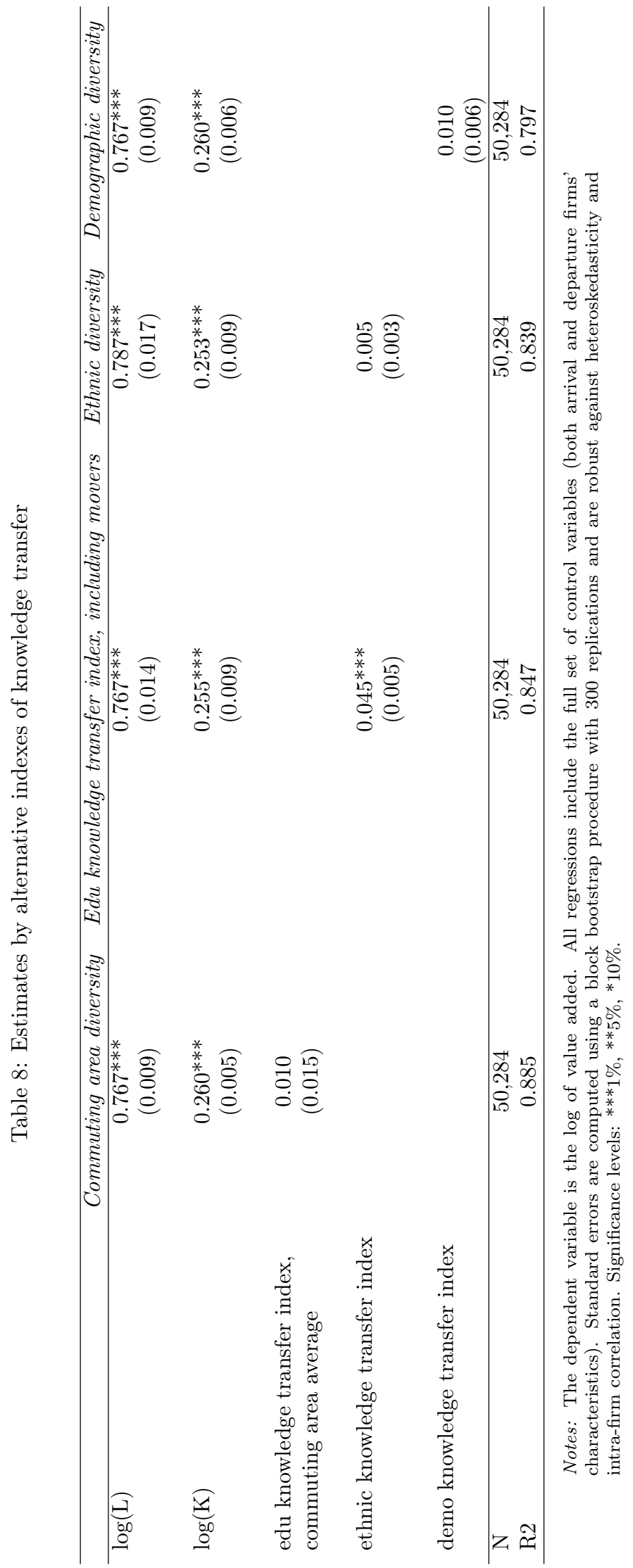




\section{Appendix 1: Ethnic and demographic diversity}

In the robustness check of section 4.2, we calculate two separate knowledge spillover indices based on the cultural and the demographic diversity of the sending firms.

Cultural diversity is represented by the languages foreign employees speak. ${ }^{24}$ It has been argued in the previous literature that linguistic distance serves as a good proxy for cultural distance (Guiso et al., 2009; Adsera and Pytlikova, 2011). Therefore, we have grouped employees together by the languages spoken in their countries of origin. This linguistic classification is more detailed than the grouping by nationality. We group countries (using the major official language spoken by the majority) at the third linguistic tree level, e.g., Germanic West vs. Germanic North vs. Romance languages. The information on languages is drawn from the encyclopedia of languages entitled Ethnologue: Languages of the World. ${ }^{25}$

\footnotetext{
${ }^{24}$ Second-generation immigrants are not treated as foreigners.

${ }^{25}$ We use the following linguistic groups: Germanic West (Antigua Barbuda, Aruba, Australia, Austria, Bahamas, Barbados, Belgium, Belize, Bermuda, Botswana, Brunei, Cameroon, Canada, Cook Islands, Dominica, Eritrea, Gambia, Germany, Ghana, Grenada, Guyana, Haiti, Ireland, Jamaica, Liberia, Liechtenstein, Luxemburg, Mauritius, Namibia, Netherlands, Netherlands Antilles, New Zealand, Saint Kitts and Nevis, Saint Lucia, Saint Vincent and Grenadines, Seychelles, Sierra Leone, Solomon Islands, South Africa, St. Helena, Suriname, Switzerland, Trinidad and Tobago, Uganda, United Kingdom, United States, Zambia, Zimbabwe), Germanic Nord (Denmark, Iceland, Norway, Sweden), Slavic West (Czech Republic, Poland, Slovakia), Slavic South (Bosnia and Herzegovina, Croatia, Serbia, Slovenia), Slavic East (Belarus, Georgia, Mongolia, Russian Federation, Ukraine), Baltic East (Latvia, Lithuania), Finno-Permic (Finland, Estonia), Ugric (Hungary), Romance (Andorra, Angola, Argentina, Benin, Bolivia, Brazil, Burkina Faso, Cape Verde, Chile, Columbia, Costa Rica, Cote D'Ivoire, Cuba, Djibouti, Dominican Republic, Ecuador, El Salvador, Equatorial Guinea, France, French Guina, Gabon, Guadeloupe, Guatemala, Guinea, Guinea Bissau, Holy See, Honduras, Italy, Macau, Martinique, Mexico, Moldova, Mozambique, Nicaragua, Panama, Peru, Portugal, Puerto Rico, Reunion, Romania, San Marino, Sao Tome, Senegal, Spain, Uruguay, Venezuela), Attic (Cyprus, Greece), Turkic South (Azerbaijan, Turkey, Turkmenistan), Turkic West (Kazakhstan, Kyrgystan), Turkic East (Uzbekistan), Gheg (Albania, Kosovo, Republic of Macedonia, Montenegro), Semitic Central (Algeria, Bahrain, Comoros, Chad, Egypt, Irak, Israel, Jordan, Kuwait, Lebanon, Lybian Arab Jamahiria, Malta, Mauritiania, Morocco, Oman, Qatar, Saudi Arabia, Sudan, Syrian Arab Republic, Tunisia, Yemen, United Arabs Emirates), Indo-Aryan (Bangladesh, Fiji, India, Maldives, Nepal, Pakistan, Sri Lanka), Mon-Khmer East (Cambodia), Semitic South (Ethiopia), Malayo-Polynesian West (Indonesia, Philippines), MalayoPolynesian Central East (Kiribati, Marshall Islands, Nauru, Samoa, Tonga), Iranian (Afghanistan, Iran, Tajikistan), Betai (Laos, Thailand), Malayic (Malasya), Cushitic East (Somalia), Viet-Muong (Vietnam), Volta-Congo (Burundi, Congo, Kenya, Lesotho, Malawi, Nigeria, Rwanda, Swaziland, Tanzania, Togo), Barito (Madagascar), Mande West (Mali), Lolo-Burmese (Burma), Chadic West (Niger), Guarani (Paraguay), Himalayish (Buthan), Armenian (Armenia), Sino Tibetan (China, Hong Kong, Singapore, Taiwan), Japonic (Japan, Republic of Korea, Korea D.P.R.O.).
} 
It is important to note that for ethnic diversity, the shares of foreign workers of different nationalities/linguistic groups in each workplace have been calculated as follows:

$$
p_{s w t}=\frac{\text { foreigners }_{s w t}}{\text { foreigners } s_{w t}}
$$

The demographic index is built from the intersection of gender and age quintiles. To measure diversity at the firm level for each of these two dimensions, we use the Herfindhal index as in (1). 
Appendix 2: Additional results

Table A2.1: Estimates by arrival firm's industry

\begin{tabular}{lccccc}
\hline & Manufacturing & Construction & Wholesale and retail trade & Transport & Financial and business service \\
\hline $\log (\mathrm{L})$ & $0.761^{* * *}$ & $0.764^{* * *}$ & $0.797^{* * *}$ & $1.058^{* * *}$ & $0.898^{* * *}$ \\
& $(0.016)$ & $(0.051)$ & $(0.040)$ & $(0.446)$ & $(0.101)$ \\
$\log (\mathrm{K})$ & $0.283^{* * *}$ & $0.286^{* * *}$ & $0.262^{* * *}$ & $0.205^{* * *}$ & $0.227^{* * *}$ \\
& $(0.010)$ & $(0.022)$ & $(0.015)$ & $(0.057)$ & $(0.029)$ \\
edu knowledge transfer index & $0.037^{* * *}$ & $0.015^{* *}$ & $0.037^{* * *}$ & 0.018 & $0.032^{* *}$ \\
& $(0.012)$ & $(0.007)$ & $(0.005)$ & $(0.066)$ & $(0.012)$ \\
\hline $\mathrm{N}$ & 35,810 & 15,511 & 26,490 & 4,389 & 7,601 \\
$\mathrm{R} 2$ & 0.917 & 0.882 & 0.844 & 0.824 & 0.802 \\
\hline
\end{tabular}

Notes: The dependent variable is the log of value added. All regressions include the full set of control variables (both arrival and departure firms' characteristics). Standard errors are computed using a block bootstrap procedure with 300 replications and are robust against heteroskedasticity and intra-firm correlation. Significance levels: ***1\%, $* * 5 \%, * 10 \%$.

Table A2.2: Estimates by arrival firm characteristics

\begin{tabular}{|c|c|c|c|c|c|}
\hline & $\leq 50$ employees & 50-99 employees & $\geq 99$ employees & Mono-establishment & Copenhagen is excluded \\
\hline \multirow[t]{2}{*}{$\log (\mathrm{L})$} & $0.809^{* * *}$ & $0.775^{* * *}$ & $0.847^{* * *}$ & $0.755 * * *$ & $0.776^{* * *}$ \\
\hline & $(0.090)$ & $(0.089)$ & $(0.129)$ & $(0.013)$ & $(0.011)$ \\
\hline \multirow[t]{2}{*}{$\log (\mathrm{K})$} & $0.256^{* * *}$ & $0.303^{* * *}$ & $0.205^{* * *}$ & $0.258^{* * *}$ & $0.252^{* * *}$ \\
\hline & $(0.010)$ & $(0.125)$ & $(0.048)$ & $(0.010)$ & $(0.006)$ \\
\hline \multirow[t]{2}{*}{ edu knowledge transfer index } & $0.037^{* * *}$ & $0.047^{* * *}$ & $0.053^{*}$ & $0.040^{* * *}$ & $0.040^{* * *}$ \\
\hline & $(0.012)$ & $(0.010)$ & $(0.029)$ & $(0.014)$ & $(0.006)$ \\
\hline $\mathrm{N}$ & 26,249 & 11,405 & 11,760 & 37,188 & 48,654 \\
\hline $\mathrm{R} 2$ & 0.874 & 0.728 & 0.787 & 0.881 & 0.834 \\
\hline
\end{tabular}

Notes: The dependent variable is the log of value added. All regressions include the full set of control variables (both arrival and departure firms' characteristics). Standard errors are computed using a block bootstrap procedure with 300 replications and are robust against heteroskedasticity and intra-firm correlation. Significance levels: ***1\%, $*^{*} 5 \%,{ }^{*} 10 \%$. 
Interactions with educationally diverse co-workers promote learning opportunities. Hiring workers from educationally diverse enterprises is productivity enhancing. This effect is larger when worker flows originate from knowledge intensive firms. This effect is stronger if movers have a higher capacity for absorbing knowledge. 